\title{
Simulate the Failure of Embankment Due to High-speed Train Moving Load
}

\author{
Ahmed Elgamal \\ Mansoura Higher Institute of Engineering and Technology \\ Mansoura, Egypt \\ Aelgamal@mc.edu.eg
}

\begin{abstract}
The stunning development of modern railways coincides with the appearance of high-speed trains, which led to an inevitability complex analysis with a focus on dynamic soil behaviour. One of the critical engineering challenges with increased speed is that dynamic behaviour which amplified within the track and supporting earthworks. The three-dimensional analyses are necessary to achieve a better simulation of train-induced ground vibrations in order to study certain effects of this problem. The developed numerical modelling must represent a realistic simulation of the railway track, trainload, and subsoil. This paper investigates the results of numerical modelling in PLAXIS 3D for simulating moving loads on a typical soft soil. Several static point loads; with amount load equal to train axle load; were applied along the railway track. The dynamic multiplier is assigned as a time-shear force signal for each point load. The shear forces calculated by modelling the beam under unit loads on the elastic foundation. The resulting shear forces in the beam were applied to the 3D model as factors of the dynamic. The results of numerical models showed that acceleration and velocity decreased with depth and increased with soil stiffness.
\end{abstract}

Keywords: PLAXIS 3D, High-speed railways, ground vibrations, soft clay, numerical modelling

\section{Introduction}

The railway track is loaded with the weight of the train that should be transmitted to a large area in order to reduce the stress in the substructure. By the rail and the sleepers, the wheel/rail contact force is transmitted from a small area of a few square centimetres to an area of up to one square meter in the subgrade. Fig. 1 shows the construction of a modern railway track.

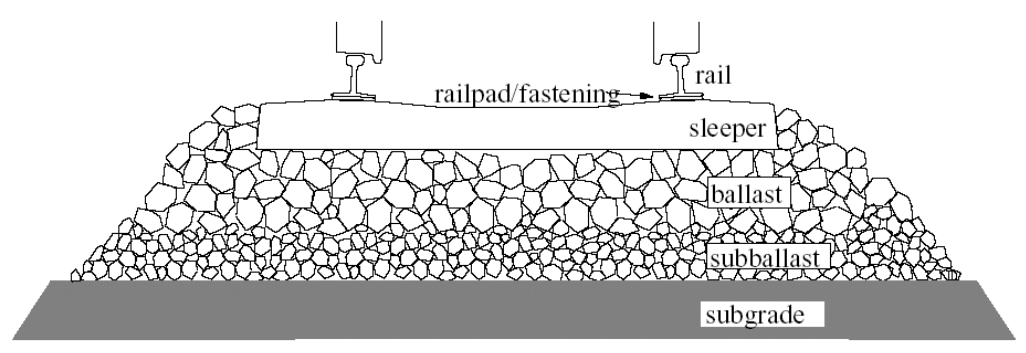

Fig. 1: Construction of a modern railway track.

The transmission of ground vibrations from a moving train to the surroundings is a complex problem dependent on a significant number of factors. The process of transmission of train-induced ground vibrations can be separated into several distinct stages, each of which impresses its own characteristics to provide new and often different input to the next stage in the process. The main problem is the high speed of trains in the railway's network where the wavelengths of the waves in both the track and soil coincide and the low-frequency energy generated due to the vehicle passage is magnified, so the track structure is subject to large-amplitude vibrations "[1] [2] [3] [4] [5] [6] [7]". The moving load changes its place during the time, and it causes large deformation compared with static loads. The developed dynamic load caused by inelastic deformation and high-speed trains trucks require a small differential settlement.

To better understand the relationship between a moving load over an elastodynamic medium, "[8] [9] [10]" approximated the problem as a moving point load on an elastic half-space. In an attempt to tailor the analysis towards railway 
problems, [11] modelled the track response analytically and used Green's functions to calculate the soil response. Alternative formulations were proposed by [12] and [13], and more recently by [14] and [15].

In contrast to analytical modelling, "[16] [17]" and [18] proposed two-dimensional (2D) finite-element (FE) models to analyse the critical velocity. Full three-dimensional (3D) approaches have also been used "[19] [20] [21] [22] [23] [24] [25]" with success; however, their run times can be prohibitive. Therefore, hybrid approaches, combining contrasting numerical methods, such as the FE method (FEM), the boundary element method (BEM) and the method of fundamental solutions, including 2.5D models, have also been developed (e.g. by [26] [27] [28] [29] [30] [31] [32]).

\section{The Train moving loads simulation}

The moving loads depend on train loads and their speed. Fig. 2 shows the trainloads (point loads), the track, and the sleeper overlays soil. The old versions of PLAXIS have lacked a feature of modelling the train's passing load and PLAXIS version 2018 is the only version has this merit. The numerical model was developed where the beam was analysed statically to calculate the shear force distribution in the rail, and then this part was rescaled along the length of the model.

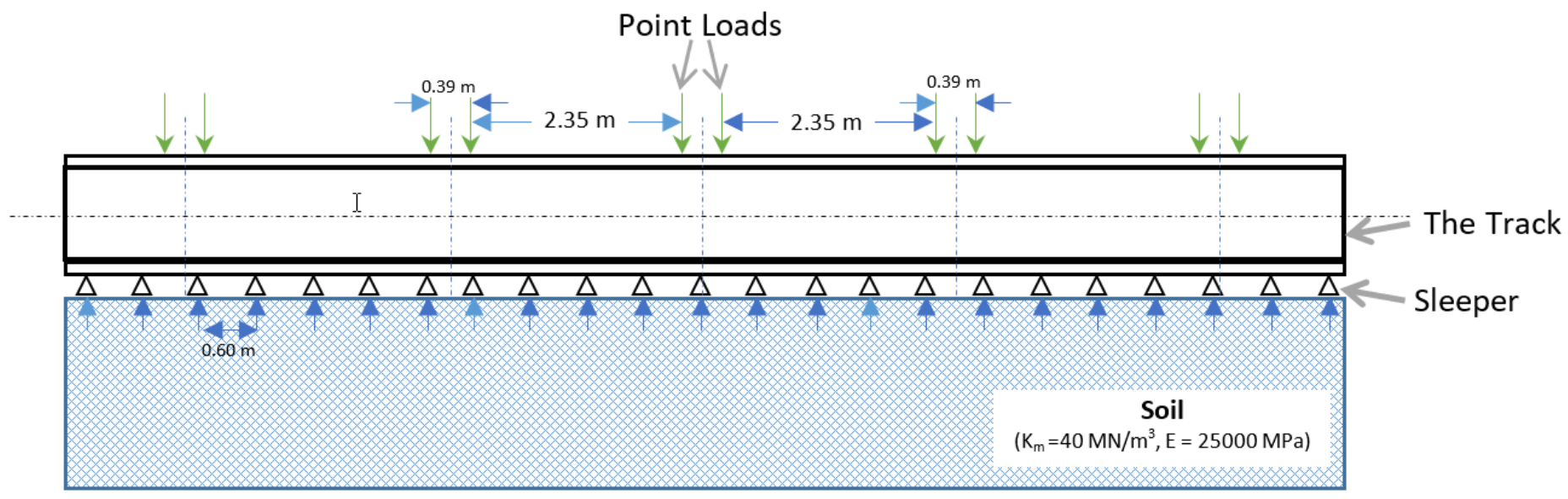

Fig. 2: The model of trainload, track, and sleeper with soil.

The PROKON (Structural Analysis, and Design software) is used to calculate the static shear force in the rail base on the theory of analysis for the beam on the elastic soils, as shown in Fig. 3. The model on PROKON was simulated as a 2D frame rested on springs with very short spacing based on linear analysis. The static analysis was conducted by using a fourunit load. The developed shear forces were then used as the dynamic multiplier for each point load in PLAXIS 3D model after rescaling to the model length.

Fig. 4 illustrates the vehicle unit chosen for this demonstration, and it is a typical German ICE3 railcar. The distance, $X$, between the first and last wagon axles is $21.6 \mathrm{~m}$, and the length has increased by $0.18 X$ on both sides to consider the effect of shear force on the impact point load. The length also increased by 0.12 in each side to take into consideration the effect of dynamic loads. The length of the loading in the rail $\left(X_{o}\right)$ is as mentioned in Eqn. (1). The total number of dynamic loads $(\mathrm{N})$ per rail calculated from Eqn. (2). The train speed is $180 \mathrm{~km} / \mathrm{hr}$., and the spacing between dynamic loads is $0.3 \mathrm{~m}$. The total time to pass the first axle $\left(t_{0}\right)$ is calculated from Eqn.(3)

$$
\begin{gathered}
X_{0}=x+2 \times(0.12+0.18) \times x=34.70 \\
N=\frac{2 \times X_{0}}{C}=117, \text { where } \mathrm{c}=\text { sleeper distance } \\
t_{0}=\text { time step } \times N=0.702
\end{gathered}
$$




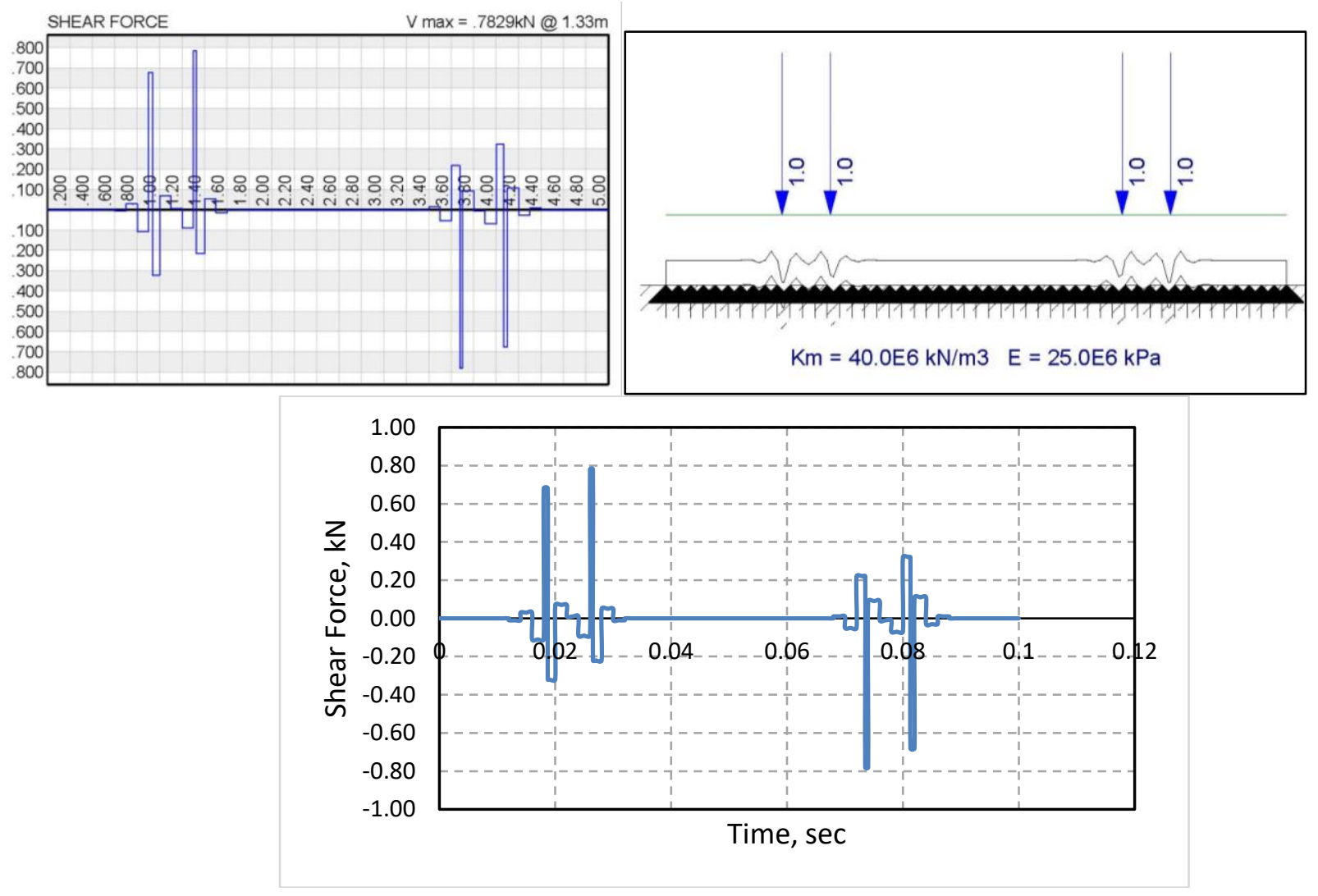

Fig. 3: Shear force in the beam on elastic soft soil using PROKON software.

The train's vehicle with a total length of $21.70 \mathrm{~m}$, needs $1.136 \mathrm{sec}$ as the total time to pass. In addition, it needs to add the time of $0.112 \mathrm{sec}$ which considered 18 added row to the multiplier to consider the relaxing and preventing of miscalculations in the model to the effect of stress wave reflection in dynamic calculations [33].

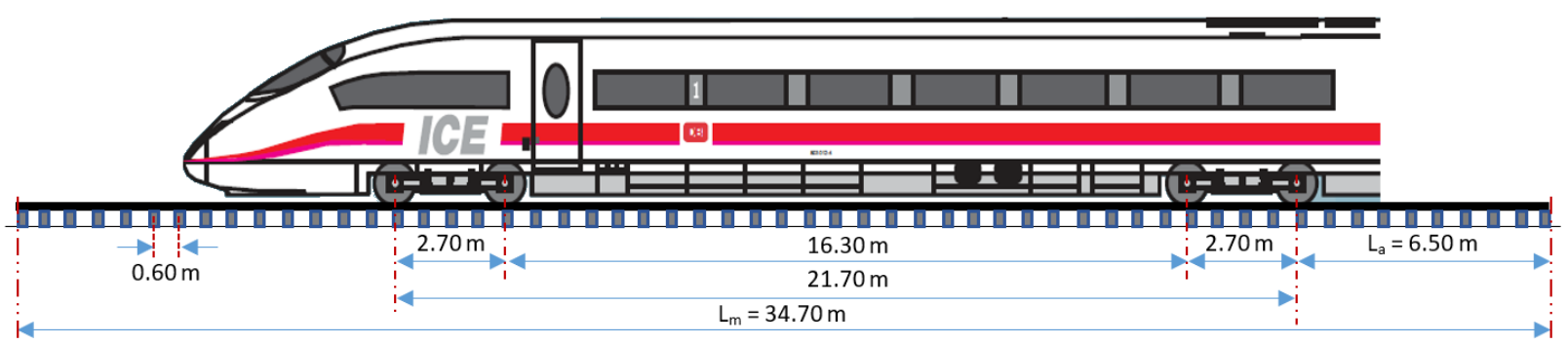

Fig. 4: Dimensions of typical German ICE3 railcar.

\section{Numerical modelling}

The popularity of using numerical prediction models is due to their ability to yield information about a mechanical system without having to physically build it. In practice, simulation replaces the physical prototype by a numerical model whose dynamic behaviour can be investigated by a computer. As the numerical prototype is far cheaper than the full-scale one, simulation is of great economic interest. Usually, results from simulation need to be validated. Once the validation step 
is performed, the proposed prediction tool is able to predict other situations. The choice of a specific solution still presents an engineering challenge. [34] concluded that the PLAXIS 2D and 3D give a good agreement compared with field data on the measurement of shear velocity and acceleration. It has proven that the linear elastic model gives near values compared with Mohr-Coulomb and hardening soil small model.

In soil dynamics, the analytical expressions to describe the wave propagation were progressively replaced by advanced numerical methods for solving railway wave propagation problems. A simple soil model classification is proposed in Fig. 5, which has the merit of considering semi-analytical models, mixing mathematical expressions of Lamb's problem and numerical tools to facilitate moving load simulation. However, pure numerical techniques are preferred to resolve dynamic soil problems and to tailor the complex wave propagation approach to railway cases [35].

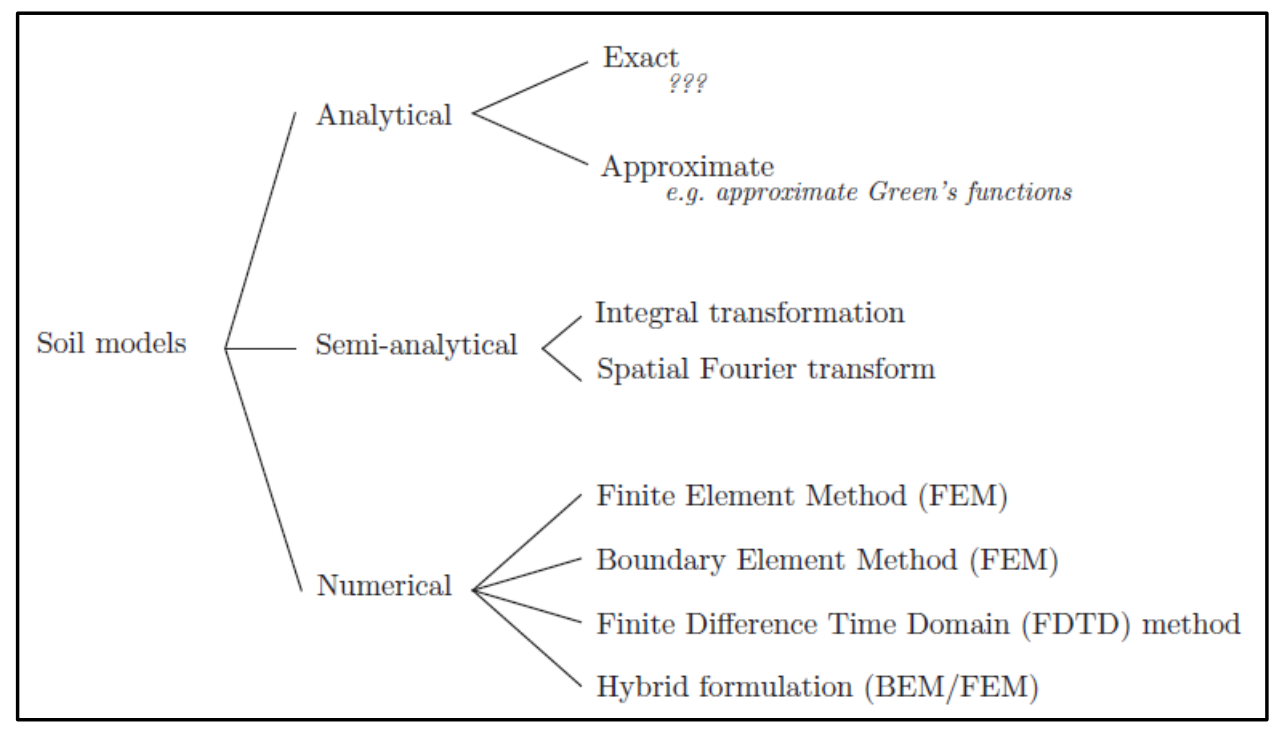

Fig. 5: Soil model classifications proposed by [36].

Viscous boundaries were applied along the edges to account for the semi-infinite extent of the soil and to prevent undue wave reflection along the boundaries [35] [36]. The Rayleigh damping coefficients are assumed to be between 10 and 100 $\mathrm{Hz}$ and $\xi=5 \%$.

In PLAXIS 3D, the dynamic multiplier is defined as a time-shear force signal. Every dynamic point load has a multiplier in every time steps. The train with speed of $180 \mathrm{~km} / \mathrm{hr}$. travels each $0.006 \mathrm{sec}$ and every $0.3 \mathrm{~m}$. Nine multiplier rows with values (shear forces) equal to zero are inserted at the beginning and the end of the multiplier, as shown in Fig. (6).

\section{Case study}

The embankment test site that is described in this paper is located on the south coast of Finland, near the town of Perniö. A non-operational railway track section that was built in the 1960s was utilized as the test site; this rail line is adjacent to the coastal railway track that connects Helsinki and Turku. a new $0.6 \mathrm{~m}$ high railway embankment having a length of $60 \mathrm{~m}$ was constructed at the existing track location, 9 weeks prior to the load test. The reason for constructing this new embankment was that the old superstructure was deemed to be too weak to support the designed loading. This small railway embankment on a soft clay foundation was brought to failure by loading over a period of $30 \mathrm{~h}$.

Hence, this study comprises 3D PLAXIS models to study the behaviour of small railway embankment on a soft clay subsoil which was brought to failure under rapid loading. 


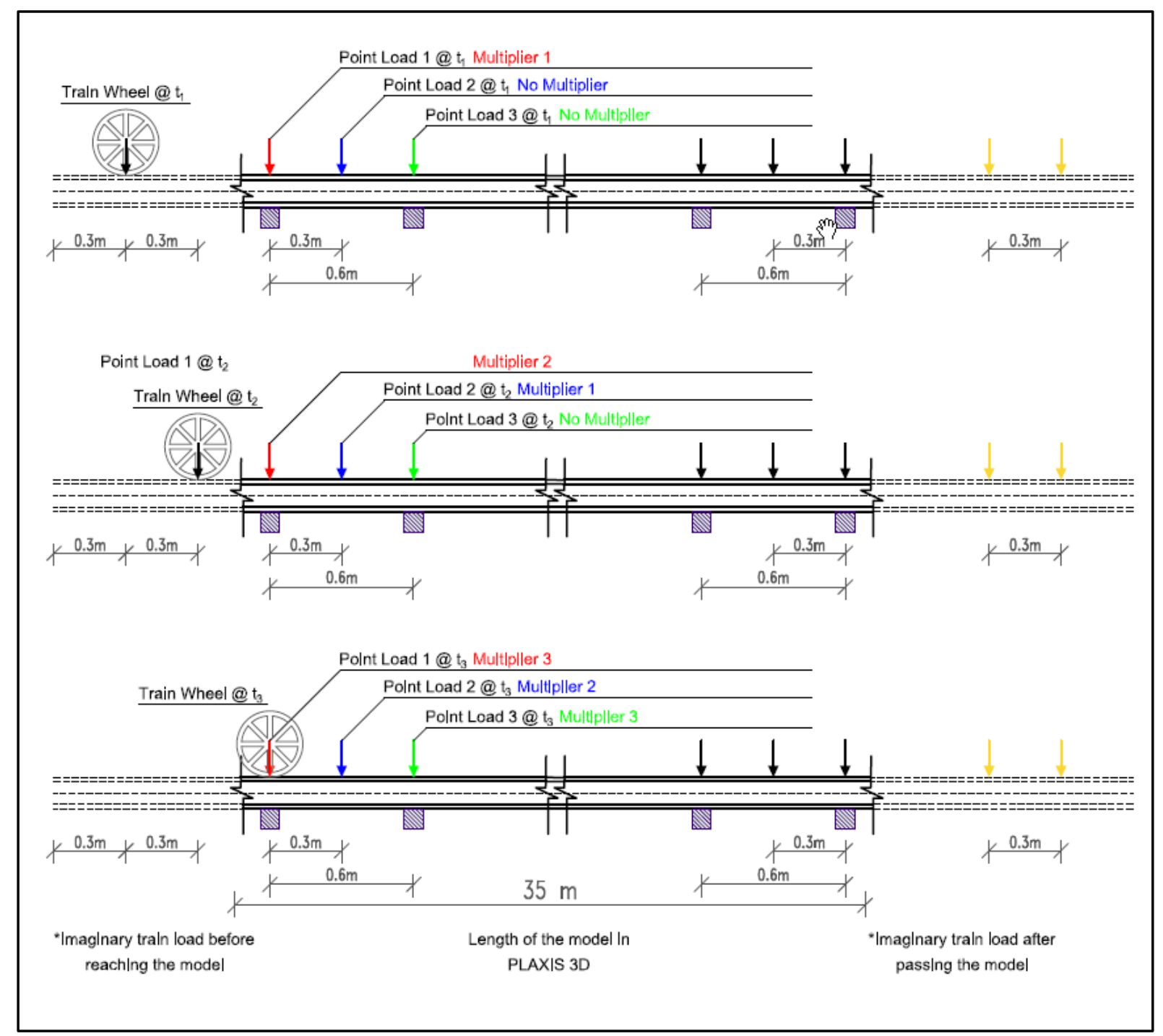

Fig. 6: Dynamic multiplier sequence.

\subsection{Field test}

[38] performed a full-scale embankment failure experiment on soft clay foundation. The railway embankment (or ballast layer) is of $0.6 \mathrm{~m}$ high and $60 \mathrm{~m}$ length. The side slopes of embankments were generally 1:2. To reduce the overall stability at the site, 10 weeks before the experiment a 0.3 to $0.6 \mathrm{~m}$ layer of topsoil was removed next to the embankment. Additionally, a $2 \mathrm{~m}$ deep ditch, $7 \mathrm{~m}$ wide, with a 1:1.5 side slope on the embankment side was excavated approximately $13.5 \mathrm{~m}$ from the embankment centreline, to further reduce stability and to control the extents of the failure. The soil profile (see fig.7) at the site consisted of:

- an old fill made of sand and gravel with a thickness of about $1.5 \mathrm{~m}$.

- a 0.6-0.9m thick weathered clay crust layer.

- a 3.5-4.5m thick, soft clay layer.

- a varved silty clay layer composed of thin clay, silt and sandy silt layers with a thickness of approximately $1.5 \mathrm{~m}$.

- a significantly stronger sand layer with a thickness ranging from 2.0 to $6.0 \mathrm{~m}$.

- a dense glacial moraine layer in which the soil explorations were terminated. 


\subsection{The modeling}

The embankment was loaded using four cars. Each car consisted of four containers. To simulate train loading, each container was gradually filled with sand. Fig. 8 illustrated applied bearing pressure beneath each car over time until embankment failure.

Where The applied load under each car is calculated using the following equation:

$$
\mathrm{q}_{\mathrm{app}}=\left(\mathrm{W}_{\mathrm{sand}}+\mathrm{W}_{\mathrm{c}}\right) / \mathrm{L}_{\mathrm{c}} \mathrm{B}_{\mathrm{c}}
$$

where $\mathrm{q}_{\mathrm{app}}=$ applied bearing pressure under a given car $(\mathrm{kPa}) ; \mathrm{W}_{\text {sand }}=$ weight of sand loaded into a given car $(\mathrm{KN})$; Wc=dead weight of the containers and framework of a given car, ca. $125 \mathrm{kN}$; $\mathrm{L}_{\mathrm{c}}=$ length of the car including spacing $=12.5 \mathrm{~m}$; and $\mathrm{B}_{\mathrm{c}}=$ width of the sleepers $=2.5 \mathrm{~m}$.

The value of mass per unit length $\left(\mathrm{m}_{\mathrm{L}}\right)$ shown on the right axis of this figure was obtained using the equation:

$$
\mathrm{mL}=\mathrm{qapp}^{*} \mathrm{Bc}
$$

The Perino field test has been modelled and analysed using the 3D finite element program (PLAXIS 3D V 2013 software). The soil stratification and railway embankment in typical 3D model is illustrated in Fig. (9).

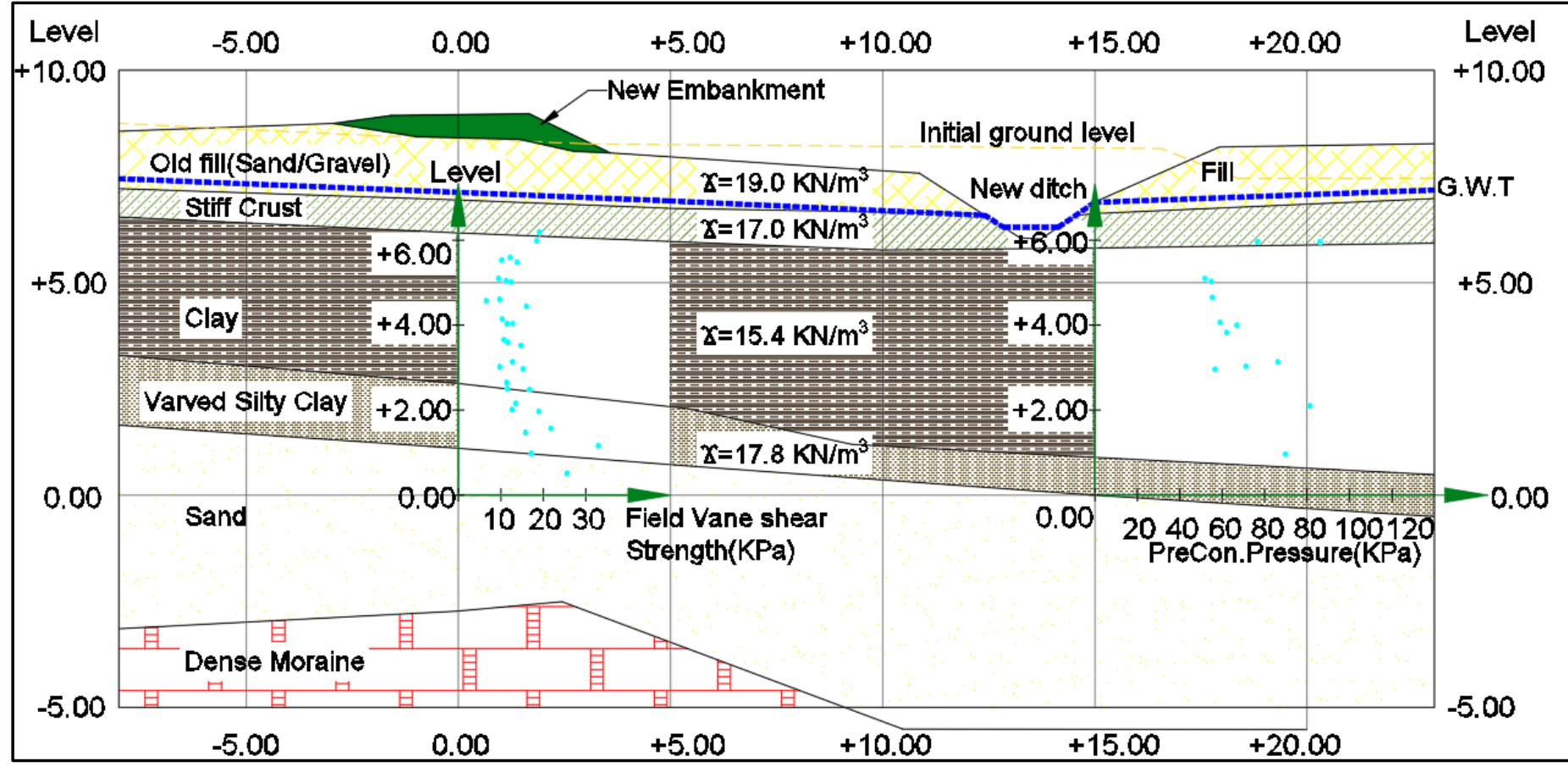

Fig. 7: Profile view of embankment test site showing soil stratigraphy inferred from the site investigation (after [38])

Table (1) illustrated the interpreted properties of ground materials used in Plaxis 3D model. The parameters of embankment (ballast layer) were recommended by Chinese railway tracks [39] due to the limitations of direct shear tests to define young's modulus. For Soft clay parameters, Compression index was calculated from liquid limit measured in the field according to [40]. 


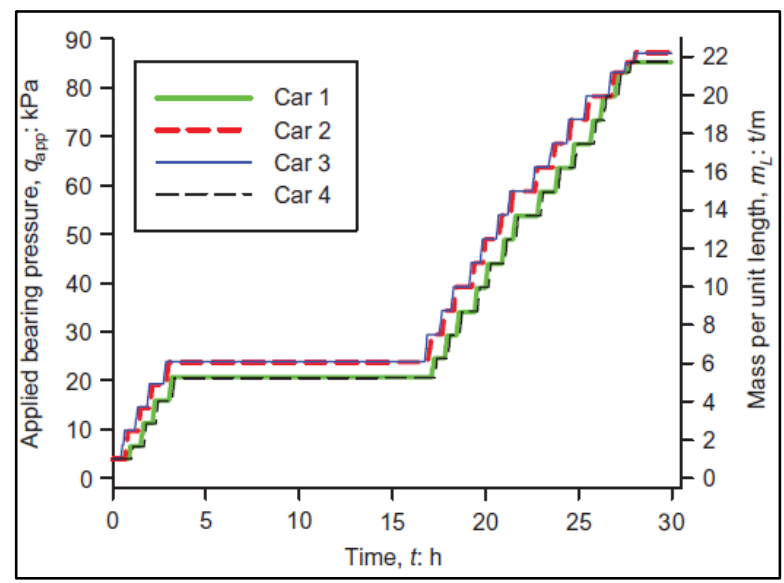

Fig. 8: Applied bearing pressure beneath each car overtime during the Perniö load test [38].

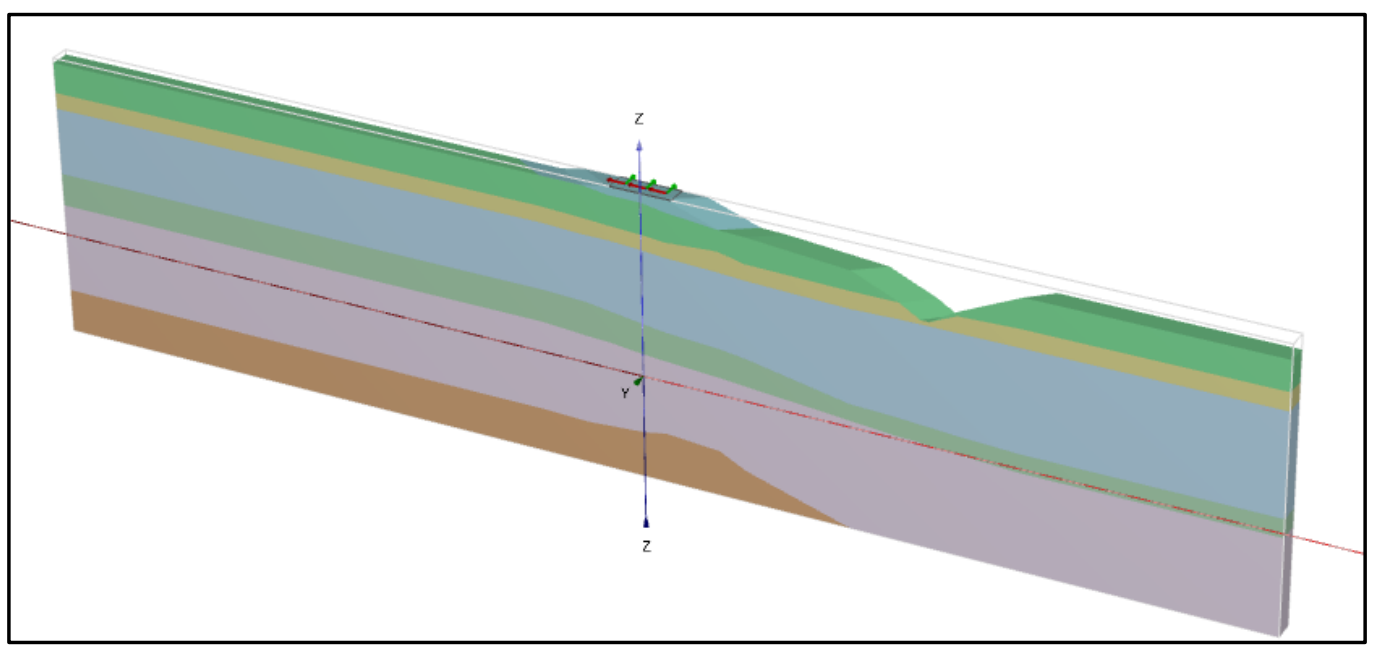

Fig. 9: Soil Stratification in Plaxis 3D model.

Table 1: Interpreted properties of the ground material.

\begin{tabular}{|c|c|c|c|c|c|c|c|c|c|}
\hline Layers & $\begin{array}{c}\text { Material } \\
\text { Modelling }\end{array}$ & $\begin{array}{c}\text { Drainage } \\
\text { Type }\end{array}$ & $\begin{array}{c}\gamma \\
\left(\mathbf{t} / \mathbf{m}^{3}\right)\end{array}$ & $\begin{array}{c}\mathbf{E} \\
(\mathbf{k P a})\end{array}$ & $\mathbf{e}_{\text {int }}$ & $\mathbf{C C}^{\prime}(\mathbf{k P a})$ & $\boldsymbol{\phi}$ & $\boldsymbol{v}_{\text {ur }}$ & $\mathbf{R}_{\text {inter }}$ \\
\hline $\begin{array}{c}\text { Stiff } \\
\text { Crust }\end{array}$ & $\begin{array}{c}\text { Mohr- } \\
\text { Coulomb }\end{array}$ & Undrained & 17.0 & 1369 & 0.5 & 25.0 & 0 & 0.30 & 1 \\
\hline Clay & $\begin{array}{c}\text { Mohr- } \\
\text { Coulomb }\end{array}$ & Undrained & 15.4 & 958 & 0.5 & 12.5 & 0 & 0.30 & 1 \\
\hline $\begin{array}{c}\text { Varved } \\
\text { silty clay }\end{array}$ & $\begin{array}{c}\text { Mohr- } \\
\text { Coulomb }\end{array}$ & Undrained & 17.8 & 1597 & 0.5 & 20.0 & 0 & 0.30 & 1 \\
\hline Old fill & $\begin{array}{c}\text { Mohr- } \\
\text { Coulomb }\end{array}$ & Drained & 19.0 & 40000 & 0.5 & 1.0 & 40 & 0.25 & 1 \\
\hline Sand & $\begin{array}{c}\text { Mohr- } \\
\text { Coulomb }\end{array}$ & Drained & 18.0 & 30000 & 0.5 & 1.0 & 31 & 0.25 & 1 \\
\hline $\begin{array}{c}\text { Embank } \\
\text { ment }\end{array}$ & $\begin{array}{c}\text { Mohr- } \\
\text { Coulomb }\end{array}$ & Drained & 19.0 & 110000 & 0.5 & 35.0 & 50 & 0.30 & 1 \\
\hline $\begin{array}{c}\text { Dense } \\
\text { Moraine }\end{array}$ & $\begin{array}{c}\text { Mohr- } \\
\text { Coulomb }\end{array}$ & Drained & 19.0 & 35000 & 0.5 & 1.0 & 38 & 0.30 & 1 \\
\hline
\end{tabular}




\subsection{Stages of Construction}

- Initial Phase: Initial Stresses generation using $\mathrm{K}_{0}$ Procedure without before applying the loads on the embankment.

- Apply surface load $=4 \mathrm{KN} / \mathrm{m}^{2}$ during one hour which simulates the dead weights of containers and framework of cars.

- Increase the surface Load until reach $20 \mathrm{KN} / \mathrm{m}^{2}$ during 4 hours.

- $\quad$ Keep surface load $=20 \mathrm{KN} / \mathrm{m}^{2}$ for 13 hours.

- Increase the surface Load until reach $87 \mathrm{KN} / \mathrm{m}^{2}$ during 10 hours.

- Keep surface load $=87 \mathrm{KN} / \mathrm{m}^{2}$ for 3 hours.

- Check the safety of embankment using safety calculations.

\subsection{Analysis and results}

In this section, the results of analyses are presented and discussed. The analysis was focused on both the shape of failure of embankment and deformations. Fig. 10 shows the best guess failure surface location that was determined by analysis of the different sensors in the field test that was performed by [38]. Fig. 11 shows the failure surface that was obtained from the numerical analyses. The obtained failure surface from field test and numerical analyses are very well matched.

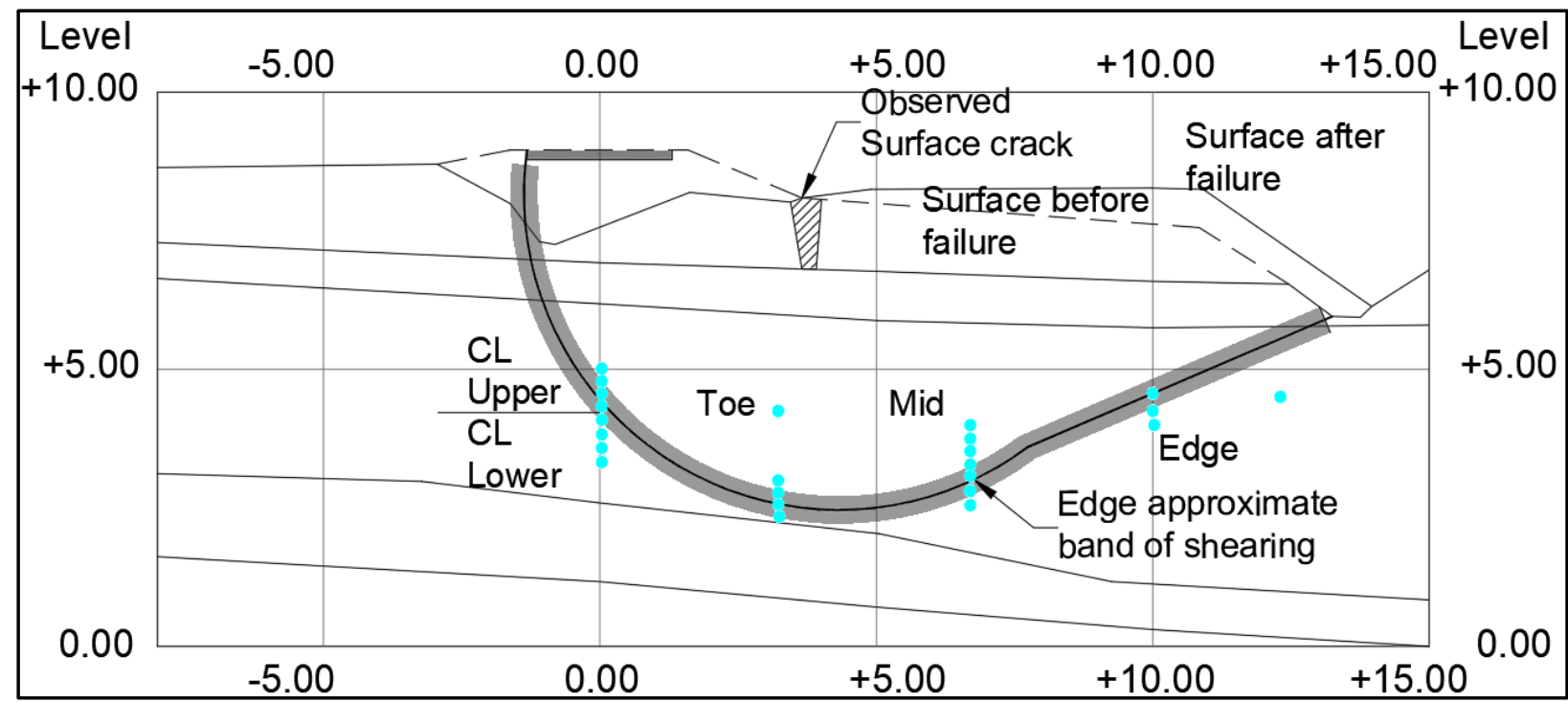

Fig. 10: Hypothesized failure surface location and general band of shearing based on overall analysis of field sensor data. Piezometer locations are shown.

Fig. 12 shows the vertical displacements measured from field test and calculated from the numerical analysis along the embankment at ( $\mathrm{t}=29$ hours). The difference between the magnitude of the measured and the calculated maximum settlement is about $23 \%(33 \mathrm{~mm} / 26 \mathrm{~mm})$. while the difference between the magnitude of the measured and the calculated maximum heave is about $18 \%(11 \mathrm{~mm} / 9 \mathrm{~mm})$. The match between the measured and calculated defamations is note-worthy.

Fig. 13 shows the lateral displacements measured from field test and calculated from the numerical analysis at the toe of the embankment at ( $\mathrm{t}=29$ hours). The most significant notes from Fig. 13 that the calculated lateral displacement was considerably higher than those measured in the field, reaching approximately double the values observed during the field test.

The discrepancy between the measured and calculated horizontal soil displacement is most probably due to the anisotropy of the soft clay fabric developed during one-dimensional consolidation. [41] [42] commented that neglecting the anisotropy of soil behaviour is likely to result in inaccurate estimations of soil displacements under embankment loading. Clearly, using a constitutive relationship based on anisotropic modulus, and inside a yield 
locus that is mirrored around the axis with zero deviatoric stress, will not reproduce a ratio of plastic deviatoric and volumetric strain increments that matches the physical model response, as demonstrated by [43], for lacustrine clay.

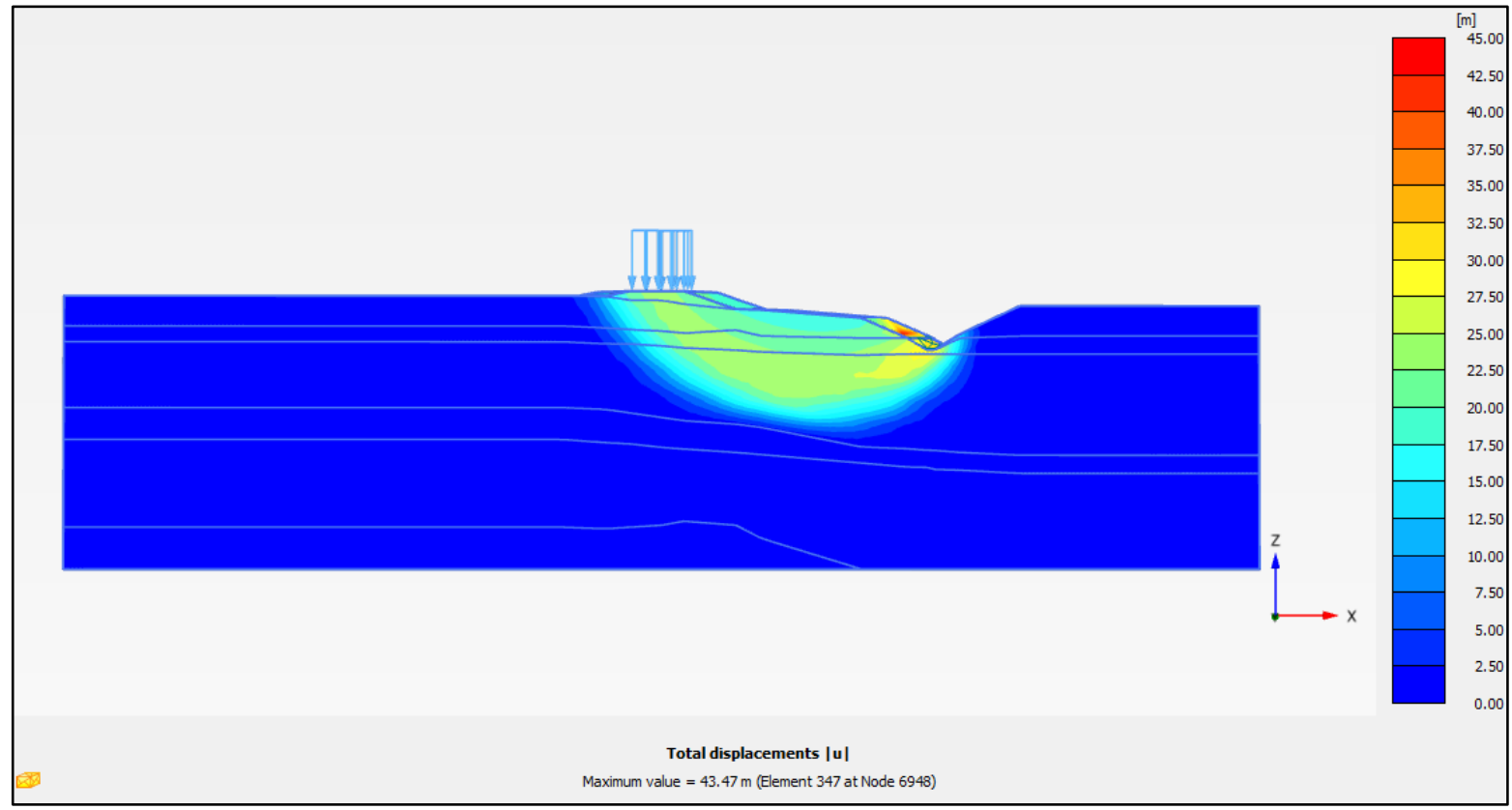

Fig. 11: Failure surface location according to 3D numerical modelling.

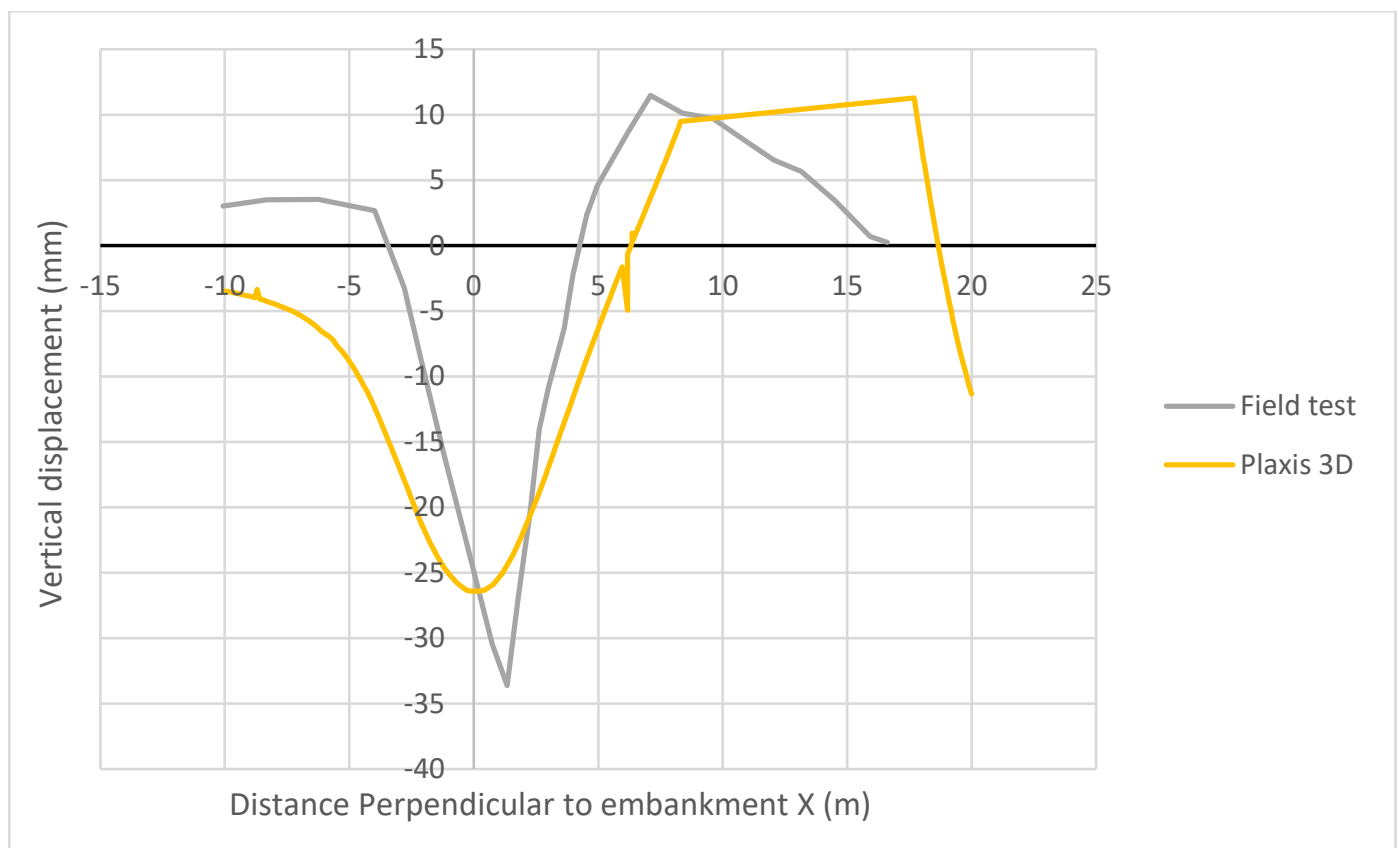

Fig. 12: Ultimate vertical displacements under the embankment. 


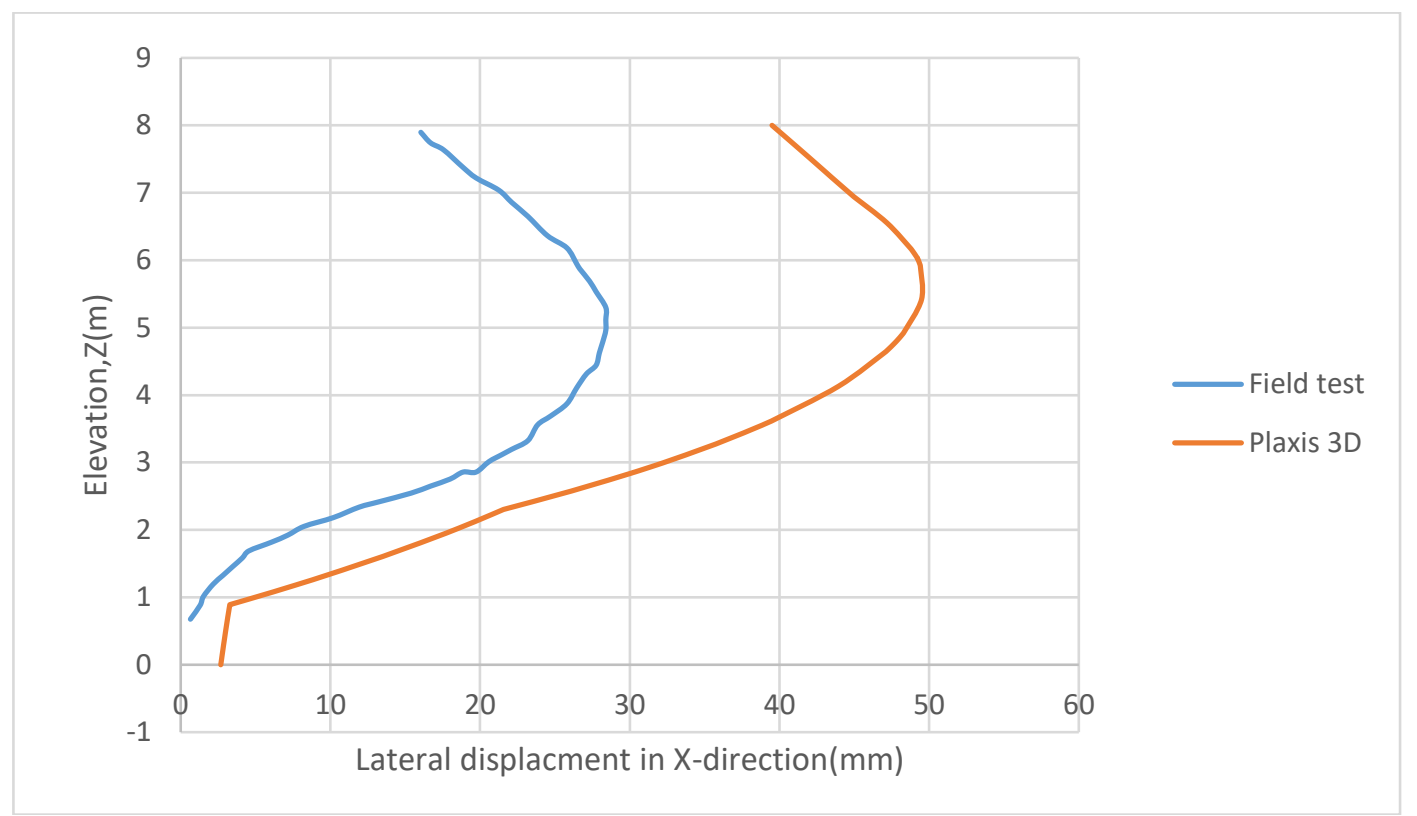

Fig. 13: Lateral displacements at the toe of the embankment.

\section{Conclusion}

A small railway embankment on soft clay subsoil was brought to failure with rapid loading, simulating a train coming to a standstill. The embankment was loaded with a "train-sized" finite area surcharge that was increased up to $87 \mathrm{kPa}$, over the course of $28 \mathrm{~h}$. The embankment failed at $\mathrm{t}=29: 57$ from the start of the experiment, under a steady, sustained surcharge of $87 \mathrm{kPa}$. 3D numerical model on Plaxis 3D was performed to simulate the field test. The findings are summarized based on the Plaxis 3D and field test as follows:

- There is a good match between the failure wedge measured in the field and calculated in the numerical model.

- The value of vertical soil movements obtained from the Plaxis 3D analyses is generally in good agreement with the measured values. However, horizontal soil movements obtained numerically are far higher than the measured values.

So it is recommended in the future to use a constitutive model that takes into consideration the anisotropic behaviour of soft clay layer.

\section{References}

[1] R. F. Woldringh and B. M. New, (1999). "Embankment design for high-speed trains on soft soils" in Proceedings of the Twelfth European Conference on Soil Mechanics and Geotechnical Engineering, The Netherlands Society of Soil Mechanics and Geotechnical Engineering, vol. 3.

[2] L. Hall, "Simulations and analyses of train- induced ground vibrations in finite element models," Soil Dynamics and Earthquake Engineering, vol. 23, no. 5, pp. 403-413, 2003.

[3] S. Witt, "The influence of under sleeper pads on railway track dynamics," 2008.

[4] H. Huang and S. Chrismer, "Discrete element modelling of ballast settlement under trains moving at "critical speeds," Construction and Building Materials, vol. 38, pp. 994-1000, 2013.

[5] D. P. Connolly, G. Kouroussis, P. K. Woodward, P. Alves Costa, O. Verlinden and M. C. Forde, "Field testing and analysis of high-speed rail vibrations," Soil Dynamics and Earthquake Engineering, vol. 67, pp. 102-118, 2014. 
[6] D. P. Connolly, P. Alves Costa, G. Kouroussis, P. Galvin, P. K. Woodward and O. Laghrouche, "Large scale international testing of railway ground vibrations across Europe," Soil Dynamics and Earthquake Engineering, vol. 71, pp. $1-12,2015$

[7] P. Wang, K. Wei, L. Wang and J. Xiao, "Experimental study of the frequency-domain characteristics of ground vibrations caused by a high-speed train running on non-ballasted track," in Proceedings of the Institution of Mechanical Engineers, Part F: Journal of Rail and Rapid Transit, vol. 230, no. 4, pp. 1131-1144, 2015.

[8] H. Lamb, "On the propagation of tremors over the surface of an elastic solid," Philosophical Transactions of the Royal Society of London. Series A, Containing Papers of a Math. or Phys.Character (1896-1934) vol. 203, pp. 1-42, 1904.

[9] J. Kenney, "Steady-state vibrations of beam on elastic foundation for moving load," Journal of Applied Mechanics, vol. 76, pp. 359-364, 1954.

[10] L. Fryba "Vibration of Solids and Structures Under Moving Loads," Noord Hoff International, Groningen, The Netherlands, 1972.

[11] V. Krylov, "Generation of ground vibrations by superfast trains," Applied Acoustics, vol. 44, no. 2, pp. 149-164, 1995.

[12] F. Barros and J. E. Luco, (1995). "Stresses and displacements in a layered half-space for a moving line load," Applied Mathematics and Computation, vol. 67, no. 1-3, pp. 103-134, 1995.

[13] H. Dieterman and A. Metrikine A (1996). The Equivalent stiffness of a half-space interacting with a beam. Critical velocities of a moving load along the beam. European Journal of Mechanics, series A, Solids 15(1): 67-90, 1996.

[14] X. Sheng, C. J. C Jones and D. J. Thompson, "A comparison of a theoretical model for quasistatically and dynamically induced environmental vibration from trains with measurements," Journal of Sound and Vibration, vol. 267, pp. 621635, 2003.

[15] D. Thompson, "Railway Noise and Vibration. Mechanisms, Modelling, and Means of Control," Elsevier, Oxford, UK, 2009.

[16] L. A. Yang, W. Powrie, and J. A. Priest, "Dynamic stress analysis of a ballasted railway track bed during train passage," Journal of Geotechnical and Geoenvironmental Engineering, vol. 135, no. 5, pp. 680, 2009.

[17] R. Ferrara, G. Leonardi, and F. Jourdan, "A two-dimensional numerical model to analyse the critical velocity of highspeed infrastructure. The 2D numerical model" in Proceedings of the Fourteenth International Conference on Civil, Structural and Environmental Engineering Computing, Cagliari, Sardinia, Italy, pp.1-16, 2013.

[18] E. Nsabimana and Y-H Jung, "Dynamic subsoil responses of a stiff concrete slab track subjected to various train speeds: a critical velocity perspective," Computers and Geotechnics, vol. 69, pp. 7-21, 2015.

[19] D. Connolly, A. Giannopoulosa, W. Fana, P. K. Woodward and M. C. Forde, "Optimising low acoustic impedance back-fill material wave barrier dimensions to shield structures from ground-borne high-speed rail vibrations," Construction and Building Materials, vol. 44, pp. 557-564, 2013.

[20] A. El Kacimi, O. K. Woodward, O. Lahrouche and G. Medero, "Time-domain 3D finite element modelling of traininduced vibration at high speed," Computers \& Structures, vol. 118, pp. 66-73, 2013.

[21] P. Galvin, A. Romero and J. Dominguez, "Fully three-dimensional analysis of high-speed train-track-soil-structure dynamic interaction," Journal of Sound and Vibration, vol. 329, no. 24, pp. 5147-5163, 2010.

[22] G. Kouroussis, O. Verlinden and C. Conti, "Free field vibrations caused by high-speed lines: measurement and timedomain simulation," Soil Dynamics and Earthquake Engineering, vol. 31, no. 4, pp. 692-707, 2010.

[23] G. Kouroussis, D. P. Connolly, K. Vogiatzis, and O. Verlinden, "Modelling the environmental effects of railway vibrations from different types of rolling stock - a numerical study," Shock and Vibration, 2015.

[24] J. Y. Shih, D. J. Thompson and A. Zervos, "The effect of boundary conditions, model size, and damping models in the finite element modelling of a moving load on a track/ground system," Soil Dynamics and Earthquake Engineering, vol. 89, pp. 12-27, 2016.

[25] J. N. Varandas, P. Hölscher, \& M. A. Silva, "Dynamic behaviour of railway tracks on transitions zones," Computers \& Structures, vol. 89, no. 13-14, pp. 1468-1479, 2011. 
[26] P. Alves Costa, R. Calcada, A. Silva Cardoso and A. Bodare, "Influence of soil non-linearity on the dynamic response of high-speed railway tracks," Soil Dynamics and Earthquake Engineering, vol. 30, no. 4, pp. 221-235, 2010.

[27] P. Alves Costa, R. Calcada and A. Silva Cardoso, "Track-ground vibrations induced by railway traffic: in-situ measurements and validation of a 2.5D FEM-BEM model," Soil Dynamics and Earthquake Engineering, vol. 32, no. 1, pp. 111-128, 2012.

[28] P. Amado-Mendes, P. Alves Costa, L. M. C. Godinho, and P. Lopes, "2.5D MFS-FEM model for the prediction of vibrations due to underground railway traffic," Engineering Structures, vol. 104, pp. 141- 154, 2015.

[29] L. Andersen, S. R. K. Nielsen, and S. Krenk, "Numerical methods for analysis of structure and ground vibration from moving loads," Computers \& Structures, vol. 85, no. 1-2, pp. 43-58, 2007.

[30] A. Colacio, P. A. Costa, and D. P. Connolly, "The influence of train properties on railway ground vibrations," Structure and Infrastructure Engineering, vol. 12, no. 5, pp. 517-534, 2015.

[31] P. Galvin and J. Dominguez, "Analysis of ground motion due to moving surface loads induced by high-speed trains," Engineering Analysis with Boundary Elements, vol. 31, no. 11, pp. 931-941, 2007.

[32] K. Noren-Cosgriff, E. G. Berggren, A. M. Kaynia, M. M. Dam and N. Mortensen, "A new method for estimation of critical speed for railway tracks on soft ground," International Journal of Rail Transportation, vol. 6, no. 4, pp. 203217, 2018.

[33] M. Shahraki, M. R. S. Sadaghiani, K. J. Witt, and T. Meier, "3D modelling of train induced moving loads on an embankment," Plaxis Bull, vol. 36, no. Autumn, pp. 10-15, 2014.

[34] M. Shahraki, M. S. Sadaghiani, K. J. Witt \& T. Meier, "Model quality investigations of induced moving loads of highspeed trains," in Proceedings of the 8th European Conference on Numerical Methods in Geotechnical Engineering, vol. 2, pp. 1169-1173, 2014.

[35] A. Kumar, D. Choudhury, J. Shukla, and D. L. Shah, "Seismic design of pile foundation for oil tank by using PLAXIS3D," Disaster Adv., vol. 8, no. 6, pp. 33-42, 2015.

[36] G. Kouroussis, D. P. Connolly \& O. Verlinden, "Railway-induced ground vibrations-a review of vehicle effects," International Journal of Rail Transportation, vol. 2, no. 2, pp. 69-110, 2014.

[37] A. Kumar, D. Choudhury, \& R. Katzenbach, "Effect of earthquake on combined pile-raft foundation," International Journal of Geomechanics, vol. 16, no. 5, 2016.

[38] V. J. Lehtonen, C. L. Meehan, T. T. Länsivaara, \& J. N. Mansikkamäki, "Full-scale embankment failure test under simulated train loading," Géotechnique, vol. 65, no. 12, pp. 961-974, 2015.

[39] S. G. Zeng, "Railway Granular Ballast," China Railway Press (in Chinese), 1997.

[40] K. Terzaghi, R. B. Peck \& G. Mesri, Soil mechanics in engineering practice. John Wiley \& Sons, 1996.

[41] S. J. Wheeler, A. Näätänen, M. Karstunen \& M. Lojander, "An anisotropic elastoplastic model for soft clays," Canadian Geotechnical Journal, vol. 40, no. 2, pp. 403-418, 2003.

[42] M. Karstunen, C. Wiltafsky, H. Krenn, F. Scharinger \& H. F. Schweiger, "Modelling the behaviour of an embankment on soft clay with different constitutive models," International Journal for Numerical and Analytical Methods in Geomechanics, vol. 30, no. 10, pp. 953-982, 2006.

[43] S. Messerklinger \& S. M. Springman, "Non-linear elasto-plastic behaviour of Lacustrine Clay," Geotechnical and Geological Engineering, vol. 28, no. 2, pp. 93-104, 2010. 